\title{
Zaginięcie przedsiębiorcy a działalność przedsiębiorstwa - zarys problemu
}

\author{
PAWEe WóJCIK \\ ORCID: 0000-0002-8682-6203 \\ Adwokat
}

Statystyki prowadzone od daty wejścia w życie Zarządzenia nr 124 Komendanta Głównego Policji pozwalają na obserwację, że od 2013 roku rocznie za zaginione uznaje się prawie 20000 osób — od 17969 osób w roku 2012 do 19563 osób w roku 2017 (policja nie opublikowała statystyk z lat następnych) ${ }^{1}$.

Celem publikacji jest zwrócenie uwagi na pomijany dotąd aspekt zaginięcia człowieka prowadzącego działalność gospodarczą.

W przeszłości zaginięcie dotyczyło człowieka jako osoby fizycznej i sytuację takiego zaginionego rozważano praktycznie wyłącznie w zakresie prawa rodzinnego, spadkowego, ubezpieczeniowego. Od czasu, gdy w Polsce zaczęła obowiązywać zasada wolności gospodarczej ${ }^{2}$, liczba przedsiębiorców znacznie wrosła - w czwartym kwartale 2018 roku liczba pracujących na własny rachunek osiągnęła 1900 000, przy czym $626000 \mathrm{z}$ nich to pracodawcy, czyli osoby zatrudniające co najmniej jednego pracownika najemnego ${ }^{3}$.

${ }^{1}$ Strona internetowa policji: http://statystyka.policja.pl/st/wybrane-statystyki/zaginieni/50885,Zaginieni.html (dostęp: 26.01.2020).

${ }^{2}$ Konstytucja Rzeczypospolitej Polskiej z dnia 2 kwietnia 1997 roku, Dz.U. 1997 $\mathrm{Nr} 78$, poz. 483, art. 22.

3 R. Zakrzewski, [w:] Raport o stanie sektora matych i średnich przedsiębiorstw w Polsce, red. R. Zakrzewski, A. Skowrońska, Warszawa 2019, s. 73. 
Tak znaczny wzrost odsetka przedsiębiorców w skali ogółu obywateli spowodował zmianę dotychczasowej sytuacji.

Zaginięcie przedsiębiorcy pociąga za sobą wiele skutków o dużej doniosłości również w innych, nie mniej istotnych, sferach życia, wywołując wątpliwości — w szczególności, czy jest on nadal zobowiązany płacić daniny publiczne i inne zobowiązania wobec osób trzecich, w jaki sposób ma to być dokonywane, czy istnieje możliwość zachowania przedsiębiorstwa poprzez umożliwienie osobom trzecim zarządzania nim pod nieobecność przedsiębiorcy i wreszcie czy możliwe jest przekazanie tego przedsiębiorstwa spadkobiercom przedsiębiorcy, jeżeli przedsiębiorca nie został odnaleziony lub po zaginięciu nastąpił jego zgon.

Co więcej, skutki zaginięcia przedsiębiorcy mogą mieć istotny wpływ nie tylko na sytuację zaginionego i jego najbliższych, ale również dla społeczeństwa, w tym pracowników, kontrahentów, klientów. Wszak prowadzona działalność gospodarcza jest zawsze powiązana z innymi podmiotami gospodarczymi oraz instytucjami państwa.

Zaginięcie przedsiębiorcy może wywołać istotne skutki dla osób zatrudnionych przez przedsiębiorcę, w szczególności wywołując niepewność, jaki jest ich status, czy i kto te osoby zatrudnia, czy powinny świadczyć pracę, na rzecz kogo i kto jest zobowiązany im wypłacać z tego tytułu wynagrodzenie.

Podobna niepewność może również mieć wpływ na pozycję kontrahentów, przede wszystkim w kontekście powiązań handlowych między przedsiębiorcami - czy zawarte umowy nadal obowiązują, czy i ewentualnie kto jest odpowiedzialny za nienależyte wykonywanie wymienionych umów po zaginięciu przedsiębiorcy.

Jak słusznie zauważa Fundacja ITAKA — Centrum Poszukiwań Ludzi Zaginionych, organizacja pozarządowa zajmująca się problemem zaginięć w Polsce,

problem zaginięcia dotyczy jednak o wiele większej liczby ludzi — rodzin i bliskich zaginionych, pracodawców, kontrahentów, wspólników, społeczność lokalną, znajomych. Zaginięcie człowieka pociąga za sobą wiele konsekwencji — również natury prawnej ${ }^{4}$.

4 J. Kowalski, Kiedy zaginą człowiek. Podstawowe informacje prawne, Warszawa 2012, http://www.itaka.org.pl/wp-content/uploads/2015/01/Kiedy-zagin\%C4\%85\%C5\%82-czowiek-informacje-prawne.pdf, s. 2 (dostęp: 26.01.2020). 
W związku ze szczególnym statusem przedsiębiorców w przypadkach zaginięcia organy prowadzące poszukiwania w przeszłości wielokrotnie przyjmowały dodatkowe wersje zdarzenia zakładające często, że była to pozoracja wynikająca $\mathrm{z}$ chęci ucieczki przed wierzycielami lub przed zobowiązaniami czy ucieczka z pieniędzmi. Inne hipotezy, mało realne w wypadku przeciętnego obywatela, ale teoretycznie możliwe $\mathrm{w}$ odniesieniu do przedsiębiorcy, to korzystanie z nielegalnego finansowania (niespłacone pożyczki od przestępców) i udział w działalności grup przestępczych (,,pranie pieniędzy”, wyłudzanie VAT itp.). Inna możliwa wersja to porwanie dla okupu ukrywane przed organami ścigania przez rodzinę. Takie wersje były chętnie przyjmowane przez policję, co tym bardziej utrudniało znalezienie przedsiębiorcy.

Jak się wydaje, w praktycznym wymiarze, naświetlenie problemu zaginięcia przedsiębiorcy również z punktu widzenia jego skutków prawnych i możliwości usunięcia jego negatywnych następstw podniesie jego rangę w ocenie instytucji zajmujących się poszukiwaniem i może przyczynić się do opracowania nowych rozwiązań.

Dla potrzeb niniejszego opracowania można przyjąć definicję legalną przedsiębiorcy zawartą przez ustawodawcę w ustawie Prawo przedsiębiorców ${ }^{5}$ jako osoby fizycznej, osoby prawnej lub jednostki organizacyjnej niebędącej osobą prawną, której odrębna ustawa przyznaje zdolność prawną, wykonującej działalność gospodarczą, przy czym przedsiębiorcami są także wspólnicy spółki cywilnej w zakresie wykonywanej przez nich działalności gospodarczej (art. 4 ust. 1 i 2). Niniejsza analiza koncentruje się na pierwszej z tych kategorii, czyli sytuacji prawnej zaginionego przedsiębiorcy, a zatem przedsiębiorcy będącego osobą fizyczną.

\section{Zaginięcie}

W aktach prawnych, takich jak Kodeks cywilny, Kodeks rodzinny i opiekuńczy oraz Kodeks postępowania cywilnego, znaleźć można takie terminy: „,zaginiony” (art. 29-32 k.c., art. XVIII-XXXIII u.p.w.k.c., art. 526-534 k.p.c.), „osoba nieobecna” (art. 184 k.r.o., art. 601 k.p.c.,

${ }^{5}$ Ustawa z dnia 6 marca 2018 roku Prawo przedsiębiorców, Dz.U. 2019 poz. 1292, tekst jednolity z dnia 12 lipca 2019. 
por. także art. 34 k.p.a.), „strona, której miejsce pobytu nie jest znane” (art. 143 i 144 k.p.c.) ${ }^{6}$.

Jak zostało wskazane wyżej, zgodnie z aktualną definicją legalną, zaginięcie to zaistnienie zdarzenia uniemożliwiającego ustalenie miejsca pobytu osoby fizycznej i zapewnienie ochrony jej życia, zdrowia lub wolności, wymagające jej odnalezienia albo udzielenia pomocy ${ }^{7}$.

$\mathrm{Z}$ powyższego wynika, że ustalenie, iż dana osoba jest zaginioną, nie jest zależne od elementu czasowego, a od nastąpienia konkretnego w skutkach zdarzenia.

Zdarzenie to, aby skutkowało uznaniem jednostki za zaginioną, musi uniemożliwiać:

1) ustalenie miejsce pobytu danej osoby fizycznej,

2) zapewnienie ochrony jej życia, zdrowia lub wolności, a jednocześnie wymagać odnalezienia danej osoby, przy czym, z uwagi na zastosowanie spójnika ,i” tworzącego koniunkcję, wszystkie te elementy muszą zostać spełnione łącznie.

Policja podejmuje czynności poszukiwania osoby zaginionej niezwłocznie po otrzymaniu informacji o zaginięciu osoby, w zależności od przyjętego poziomu poszukiwań ${ }^{8}$.

\section{Skutki prawne zaginięcia przedsiębiorcy}

Śmierć człowieka wywołuje istotne skutki cywilnoprawne. Niezależnie od utraty zdolności prawnej i zdolności do czynności prawnych śmierć wywołuje np. bezpośrednie skutki w zakresie dziedziczenia, w szerokim znaczeniu tego pojęcia, a także w zakresie możliwości zawarcia przez pozostałego przy życiu małżonka nowego małżeństwa ${ }^{9}$.

6 A. Wentkowska, Poszukiwania osób zaginionych. System i metody działania w procedurach stużb, Warszawa 2016, https://www.rpo.gov.pl/sites/default/files/Poszukiwania\%20osób\%20zaginionych\%20-\%20Aleksandra\%20Wentkowska\%20-monografia\%202016.pdf, s. 5 (dostęp: 26.01.2020).

7 Zarządzenie nr 48 Komendanta Głównego Policji z dnia 28 czerwca 2018 roku w sprawie prowadzenia przez Policję poszukiwania osoby zaginionej oraz postępowania w przypadku ujawnienia osoby o nieustalonej tożsamości lub znalezienia nieznanych zwłok oraz szczątków ludzkich, Dziennik Urzędowy Komendy Głównej Policji 2018, poz. 77.

8 Ibidem, $\S 3$ ust. 1.

9 J. Ciszewski, P. Nazaruk, Komentarz do art. 29 k.c., [w:] Kodeks Cywilny. Komentarz, red. J. Ciszewski, P. Nazaruk, WKP 2019. 
Jednoosobowa działalność gospodarcza, jako byt nierozerwalnie związany z przedsiębiorcą, przestaje istnieć wraz z jego śmiercią.

Co więcej, wykreślenie przedsiębiorcy z CEIDG następuje niezwłocznie po upływie dwóch miesięcy od dnia śmierci albo znalezienia zwłok przedsiębiorcy, nie później niż w terminie siedmiu dni od dnia, w którym upłynął ten okres (art. 30 ust. 2 i 5$)^{10}$.

Takich skutków jednak nie wywołuje samo zaginięcie, które ze swej istoty nie ma charakteru terminalnego.

Powszechnie przyjmuje się, że zaginięcie nie jest przeszkodą dla uznania osoby fizycznej za przedsiębiorcę, gdyż do chwili uznania za zmarłego osoba ta uznawana jest za istniejącą, a tym samym posiada także zdolność prawną ${ }^{11}$.

Zatem sytuacja prawna przedsiębiorcy $\mathrm{w}$ chwili zaginięcia nie zmienia się. Przedsiębiorstwo w sytuacji zaginięcia przedsiębiorcy nadal funkcjonuje. Kontynuowanie w tym okresie działalności gospodarczej zaginionego, w tym fakt pozostawania przez taką osobę w spółce cywilnej, powoduje powstanie szeregu zobowiązań, zarówno w sferze publicznoprawnej, jak odprowadzanie składek do ZUS czy podatków, jak i w sferze prywatnoprawnej. Obowiązki nałożone na przedsiębiorcę w zakresie powyższych aspektów aktualizują się bez względu na fakt, czy nieobecność przedsiębiorcy jest zawiniona, czy też nie, a oczywistym jest, że zaginiony przedsiębiorca nie jest w stanie zajmować się swoimi sprawami majątkowymi, a tym bardziej wypełnić nałożone nań zobowiązania.

$\mathrm{Z}$ zaginięciem przedsiębiorcy powiązany jest szereg problemów, przede wszystkim dla:

1) osób zatrudnionych przez przedsiębiorcę — w szczególności niepewność, jaki jest ich status, czy i kto te osoby zatrudnia, czy powinny świadczyć pracę, na rzecz kogo i kto jest zobowiązany im wypłacać $\mathrm{z}$ tego tytułu wynagrodzenie;

2) kontrahentów - w szczególności w kontekście powiązań handlowych między przedsiębiorcami, czy zawarte umowy nadal obowiązują,

${ }^{10}$ Ustawa z dnia 6 marca 2018 roku o Centralnej Ewidencji i Informacji o Działalności Gospodarczej i Punkcie Informacji dla Przedsiębiorcy, Dz.U. 2019 poz. 1291, tekst jednolity z dnia 12 lipca 2019.

11 P. Zaporowski et al., Polskie prawo firmowe. Zagadnienia wybrane, Wrocław 2016, http://bibliotekacyfrowa.pl/Content/76594/Zaporowski_P_Polskie_prawo_firmowe_zagadnienia_wybrane.pdf, s. 24 (dostęp: 26.01.2020).

Nowa Kodyfikacja Prawa Karnego 56, 2020

(C) for this edition by CNS 
czy i ewentualnie kto jest odpowiedzialny za nienależyte wykonywanie wymienionych umów po zaginięciu przedsiębiorcy.

Opisane wyżej podmioty wobec nieobecności przedsiębiorcy nie mają możliwości modyfikacji trwających stosunków pracy, czy też stosunków zobowiązaniowych. Dla opisanych wyżej podmiotów powstaje również wątpliwość, czy pod nieobecność przedsiębiorcy mogą skutecznie rozwiązać zawiązany z przedsiębiorcą stosunek, co w sposób oczywisty uderza w pewność obrotu gospodarczego.

Poza sytuacjami, gdy przedsiębiorca odnalazł się w krótkim odstępie czasu, a jego nieobecność nie miała istotnego wpływu na funkcjonowanie przedsiębiorstwa, przedsiębiorstwo nie jest przecież faktycznie zarządzane.

Co więcej, o ile ta nieuregulowana sytuacja zaginionego przedsiębiorcy może trwać przez znaczny okres czasu, o tyle sam przedsiębiorca może przecież nigdy nie zostać odnaleziony.

W ekstremalnych sytuacjach może dojść do konieczności zastosowania instytucji przewidzianej art. 29 k.c., zgodnie z którym zaginiony może być uznany za zmarłego.

Zwraca przy tym uwagę długi okres czasu, po którym przedsiębiorca może zostać uznany za zmarłego — dopiero jeżeli upłynęło lat dziesięć od końca roku kalendarzowego, w którym według istniejących wiadomości jeszcze żył; upływ lat pięciu wystarczy w sytuacjach, gdy w chwili uznania za zmarłego zaginiony ukończył lat siedemdziesiąt (art. 29 § 1 i 2 k.c.).

Regulowane przez prawo materialne (art. 29-32 k.c.) i procesowe (art. 526-534 k.p.c.) uznanie za zmarłego ma co prawda charakter konstytutywny ze skutkiem wstecznym (ex tunc) i stwarza ono w zasadzie takie skutki prawne jak śmierć człowieka ${ }^{12}$, a zatem pozwala na ustalenie wstecznej daty śmierci zaginionego, należy jednak zwrócić uwagę, że upływ czasu niezbędny do skutecznego rozpoznania wniosku o uznanie za zmarłego powoduje, że w przedsiębiorstwie mogą nastąpić nieusuwalne już zmiany ${ }^{13}$.

12 J. Ciszewski, P. Nazaruk, op. cit.

13 Średni czas trwania postępowania sądowego od dnia pierwszej rejestracji do dnia uprawomocnienia się sprawy w pierwszej instancji w sądach rejonowych w postępowaniu nieprocesowym w pierwszym półroczu 2017 roku wynosił 7,7 miesiąca (Podstawowa informacja o działalności sądów powszechnych - I pótrocze 2017 roku na tle 
Co więcej, w związku z toczącym się postępowaniem o uznanie za zmarłego może dojść do dalszej komplikacji sytuacji przedsiębiorstwa należącego do zaginionego przedsiębiorcy, albowiem z istoty tej instytucji nie można nigdy wykluczyć, że osoba zaginiona jednak żyje i konieczne jest uchylenie postanowienia o uznaniu za zmarłego (art. 539 k.p.c.) oraz skutków prawnych takiego uchylenia ${ }^{14}$. W przypadku ustalenia, że osoba uznana za zmarłą lub ta, której zgon stwierdzono, żyje, sąd wydaje postanowienie o uchyleniu poprzedniego postanowienia.

Tak znaczny upływ czasu może wiązać się z nieodwracalnymi konsekwencjami dla przedsiębiorcy i jego przedsiębiorstwa, ale również jego kontrahentów, co wiąże się z daleko idącymi skutkami dla społeczeństwa jako całości.

Biorąc powyższe pod uwagę, zdumiewa w polskim porządku prawnym brak rozwiązań pozwalających na kompleksowe i skuteczne uregulowanie sytuacji prawnej zaginionego przedsiębiorcy na mocy samych przepisów, bez przynajmniej wcześniejszego udziału przedsiębiorcy lub osób trzecich mających swój interes w zachowaniu przedsiębiorstwa.

Istniejące rozwiązania prawne są dalece niewystarczające, biorąc pod uwagę wcześniej wskazane skutki w zakresie ustania czy nawet tylko zawieszenia procesu decyzyjnego w zarządzaniu przedsiębiorstwem po zaginięciu przedsiębiorcy.

\section{Rozwiązania prawne mogące znaleźć zastosowanie w sytuacji zaginięcia przedsiębiorcy}

Do rozwiązań przewidzianych w prawie należą przede wszystkim instytucje:

1) niezależne od wiedzy i woli przedsiębiorcy:

a) prowadzenie cudzych spraw bez zlecenia,

b) kurator absentis,

poprzednich okresów statystycznych, s. 24, https://www.isws.ms.gov.pl/pl/baza-statystyczna/publikacje/ (dostęp: 26.01.2020)).

14 J. Ciszewski, P. Nazaruk, op. cit. 
2) zależne od wiedzy i woli przedsiębiorcy:
a) pełnomocnictwo,
b) prokura,
c) zarząd sukcesyjny przedsiębiorstwem osoby fizycznej.

\section{1a. Prowadzenie cudzych spraw bez zlecenia}

Podstawowa instytucja, jaka może zostać zastosowana w sytuacji zaginięcia przedsiębiorcy, to przejęcie prowadzenia spraw przedsiębiorcy przez osobę trzecią bez udzielonego pełnomocnictwa, na podstawie przepisów o prowadzeniu cudzych spraw bez zlecenia.

Wszak zgodnie z treścią art. 752 k.c., kto bez zlecenia prowadzi cudzą sprawę, powinien działać z korzyścią osoby, której sprawę prowadzi, i zgodnie z jej prawdopodobną wolą, a przy prowadzeniu sprawy obowiązany jest zachowywać należytą staranność.

\section{1b. Ustanowienie kuratora absentis}

Podstawowym rozwiązaniem przewidzianym prawem, które można zastosować w stosunku do osoby przedsiębiorcy w wypadku jego zaginięcia, jest instytucja kuratora absentis.

Ustawodawca w art. $184 \S 1$ k.r.o. przewidział instytucję kuratora dla ochrony praw osoby, która z powodu nieobecności nie może prowadzić swoich spraw, a nie ma pełnomocnika, oraz gdy pełnomocnik nieobecnego nie może wykonywać swoich czynności albo gdy je wykonywa nienależycie.

Już na wstępie rozważań należy zauważyć, że wymieniony przepis dotyczy „osoby nieobecnej”, które to pojęcie zawiera w swoim zbiorze pojęcie „osoby zaginionej”.

Osobą nieobecną w świetle tego przepisu jest nie tylko osoba, której miejsce pobytu nie jest znane, ale również osoba, która ze względu na pobyt w innym miejscu nie może osobiście prowadzić swoich spraw ${ }^{15}$.

Pozostaje sporne, czy sąd może ustanowić kuratora z urzędu, czy też wyłącznie na wniosek osoby zainteresowanej.

15 J. Wierciński, Komentarz do art. 184 k.r.o., [w:] Kodeks rodzinny i opiekuńczy. Komentarz, red. J. Wierciński, WKP 2014. 
Ma to istotne znaczenie z punktu widzenia ochrony interesów przedsiębiorcy, który przecież sam nie jest w stanie takiego wniosku złożyć.

Jak się jednak wydaje, w świetle wyraźnego brzmienia art. 601 k.p.c. należy taką możliwość wykluczyć, przepis stanowi bowiem wyjątek od ogólnej zasady działania z urzędu sądu opiekuńczego.

Możliwość ustanowienia kuratora absentis przez sąd z urzędu zachodzi w postępowaniu nieprocesowym. Zgodnie z art. $510 \S 2$ zd. 3 k.p.c. w razie potrzeby wyznaczenia kuratora do zastępowania zainteresowanego, którego miejsce pobytu jest nieznane, jego wyznaczenie następuje z urzędu.

\section{2a. Udzielenie pełnomocnictwa}

Przedsiębiorca, aby zabezpieczyć swoje interesy na wypadek zaginięcia, może przede wszystkim udzielić osobie trzeciej pełnomocnictwa ogólnego obejmującego umocowanie do czynności zwykłego zarządu oraz rodzajowego do czynności przekraczających zakres zwykłego, a jeżeli wymaga tego ustawa - pełnomocnictwa do dokonania poszczególnej czynności (art. 98 k.c.).

Pełnomocnictwo ogólne jest pełnomocnictwem o najszerszym zakresie umocowania, obejmuje umocowanie do dokonywania czynności zwykłego zarządu. A. Kidyba słusznie zauważa, że

przepisy nie definiują tych pojęć ani w sposób pozytywny przez wskazanie, jakie czynności należy zaliczyć do zwykłego zarządu (zwykłych czynności), ani w sposób negatywny, przez określenie czynności, które nie wchodzą w zakres zwykłego zarządu (zwykłych czynności). Rozumienie tych pojęć nie może bowiem zostać określone in abstracto, w oderwaniu od przedmiotu takich czynności (rzecz wspólna, majątek, zajęta nieruchomość, sprawy spółki), a także od okoliczności konkretnego przypadku ${ }^{16}$.

\section{2b. Ustanowienie prokury}

Bardziej elastyczną opcją dla przedsiębiorców, którzy nie są w stanie lub nie chcą przewidzieć w treści pełnomocnictwa wszystkich czynności niezbędnych do prowadzenia działalności gospodarczej, jest udzielenie szczególnego pełnomocnictwa, jakim jest prokura - pełnomocnictwo udziela-

16 A. Kidyba, Komentarz do art. 98 k.c., [w:] Kodeks cywilny. Komentarz, t. 1. Część ogólna, red. A. Kidyba, WKP 2012. 
ne przez przedsiębiorcę podlegającego obowiązkowi wpisu do CEIDG lub KRS, które obejmuje umocowanie do czynności sądowych i pozasądowych, jakie są związane z prowadzeniem przedsiębiorstwa (art. $109^{1} \S 1$ k.c.).

W poprzednim stanie prawnym nie było możliwe ustanowienie prokury przez jednoosobowego przedsiębiorcę prowadzącego działalność gospodarczą. Zmiana pozwalająca na powyższe została wprowadzona dopiero ustawą z dnia 6 marca 2018 roku Przepisy wprowadzające ustawę Prawo przedsiębiorców oraz inne ustawy dotyczące działalności gospodarczej.

Jak wskazano w uzasadnieniu projektu ustawy, nie można było znaleźć logicznego uzasadnienia dla rozróżniania uprawnień przedsiębiorców będących osobami fizycznymi oraz przedsiębiorców niebędących osobami fizycznymi w zakresie prokury. Zwrócono uwagę na brzmienie art. 109 (7) § 4 k.c., który to stanowi, że śmierć przedsiębiorcy ani utrata przez niego zdolności do czynności prawnych nie powoduje wygaśnięcia prokury, co jest charakterystyczne właśnie dla osób fizycznych.

Przyjęcie powyższego rozwiązania ma przemożne znaczenie dla zapewnienia możliwości zabezpieczenia interesów przedsiębiorcy na wypadek jego zaginięcia.

Prokura jest szczególnym rodzajem pełnomocnictwa udzielanego przez przedsiębiorcę, co oznacza, że prokurent działa w imieniu i ze skutkami dla reprezentowanego przedsiębiorcy, wywołując swoim zachowaniem skutki bezpośrednio w sferze reprezentowanego. Prokurent składa własne oświadczenie woli, w imieniu reprezentowanego podmiotu, ze skutkiem bezpośrednim dla tego podmiotu.

\section{2c. Ustanowienie zarządu sukcesyjnego przedsiębiorstwem osoby fizycznej}

Niezależnie od powyższych rozwiązań należy zwrócić uwagę na fakt, że ustawodawca przewidział możliwość ustanowienia zarządu sukcesyjnego przedsiębiorstwem osoby fizycznej ${ }^{17}$.

17 Ustawa z dnia 5 lipca 2018 roku o zarządzie sukcesyjnym przedsiębiorstwem osoby fizycznej i innych ułatwieniach związanych z sukcesją przedsiębiorstw, Dz.U. 2018 poz. 1629. 
Dla samego zabezpieczenia interesów zaginionego przedsiębiorcy na wypadek jego odnalezienia wymieniona instytucja samodzielnie nie ma większego znaczenia, gdyż aktualizuje się ona nie w sytuacji zaginięcia przedsiębiorcy, a na wypadek jego śmierci.

Ustawa o zarządzie sukcesyjnym przedsiębiorstwem osoby fizycznej reguluje zasady tymczasowego zarządzania przedsiębiorstwem po śmierci przedsiębiorcy, który we własnym imieniu wykonywał działalność gospodarczą na podstawie wpisu do CEIDG, oraz kontynuowania działalności gospodarczej wykonywanej z wykorzystaniem tego przedsiębiorstwa (art. 1 pkt 1).

J. Bieluk słusznie zwraca uwagę, że ustawa ma w założeniu zawierać regulacje tymczasowe. Celem tych rozwiązań, a przede wszystkim instytucji zarządu sukcesyjnego, jest jednak osiągnięcie trwałych skutków w postaci kontynuacji działalności gospodarczej przez osobę (osoby), która na skutek spadkobrania lub np. sprzedaży przedsiębiorstwa będzie już na stałe zarządzać przedsiębiorstwem. Zarząd sukcesyjny jest więc instytucją przejściową i należy interpretować przepisy ustawy, biorąc to pod uwagę ${ }^{18}$.

Zaproponowane przez ustawodawcę rozwiązanie znajduje zastosowanie wobec przedsiębiorców jednoosobowych będących osobami fizycznymi, które we własnym imieniu wykonują działalność gospodarczą, a jej celem jest zapewnienie sprawnego funkcjonowania przedsiębiorstwa $\mathrm{w}$ razie śmierci takiego przedsiębiorcy i zapewnienie sukcesji działającego przedsiębiorstwa.

Pozytywnie należy ocenić prostotę ustanowienia zarządcy sukcesyjnego.

Do ustanowienia zarządu sukcesyjnego wymagane jest:

1) powołanie zarządcy sukcesyjnego,

2) wyrażenie zgody przez osobę powołaną na zarządcę sukcesyjnego na pełnienie tej funkcji,

3) dokonanie wpisu do CEIDG zarządcy sukcesyjnego.

W myśl art. 9 ust. 1 u.z.s. przedsiębiorca może powołać zarządcę sukcesyjnego w ten sposób, że:

1) wskaże określoną osobę do pełnienia funkcji zarządcy sukcesyjnego albo

18 J. Bieluk, Komentarz do art. 1, [w:] Ustawa o zarządzie sukcesyjnym przedsiębiorstwem osoby fizycznej. Komentarz, wyd. 1, Warszawa 2019. 
2) zastrzeże, że z chwilą jego śmierci wskazany prokurent stanie się zarządcą sukcesyjnym.

Szczególne znaczenie dla dalszych rozważań ma w tym wypadku instytucja prokurenta, którego wystarczy powołać w drodze jednostronnej czynności prawnej dokonanej w formie pisemnej pod rygorem nieważności (art. 9 ust. 2). Wskazanie zaś określonej osoby, dokonane w tej samej formie, winno po prostu określać daną jednostkę.

Zarząd sukcesyjny na podstawie wyboru przedsiębiorcy zostaje ustanowiony z chwilą śmierci przedsiębiorcy (art. 7 ust. 1 pkt 1$)^{19}$.

Ustanowiony zarządca sukcesyjny od chwili ustanowienia obejmuje zobowiązanie do prowadzenia przedsiębiorstwa w spadku oraz umocowanie do czynności sądowych i pozasądowych związanych z prowadzeniem przedsiębiorstwa w spadku (art. 18).

Od daty ustanowienia zarządca sukcesyjny

zgodnie z art. 1 u.z.s. „tymczasowo zarządza przedsiębiorstwem po śmierci przedsiębiorcy oraz kontynuuje działalność gospodarczą wykonywaną z wykorzystaniem tego przedsiębiorstwa". Jest to kwestia nie bez znaczenia, gdyż zarządca sukcesyjny zostaje powołany do zarządzania przedsiębiorstwem oraz kontynuowania działalności gospodarczej wykonywanej z wykorzystaniem przedsiębiorstwa przedsiębiorcy we własnym imieniu, choć na rachunek właścicieli przedsiębiorstwa w spadku. Zostaje tym samym powołany do „zachowania” tego przedsiębiorstwa oraz przekazania go, w stanie względnie niezmienionym, następcom prawnym zmarłego. Podczas dokonywania powyższych czynności przysługują mu wszystkie prawa oraz ograniczony jest tymi samymi obowiązkami, które odnosiły się do zmarłego przedsiębiorcy. Ponadto, zgodnie z art. 18 u.z.s., jest on zobowiązany verba legis do „prowadzenia przedsiębiorstwa w spadku”. [...] Należy stwierdzić, że zarządca sukcesyjny nie tylko prowadzi/wykonuje działalność gospodarczą, ale co więcej - kontynuuje działalność gospodarczą z wykorzystaniem przedsiębiorstwa zmarłego przedsiębiorcy ${ }^{20}$.

Wobec krótkiego okresu obowiązywania przepisów o zarządzie sukcesyjnym trudno jest na tym etapie ocenić zakres i wpływ instytucji zarządcy sukcesyjnego na sytuację przedsiębiorstw zmarłych przedsiębiorców, jednak wymienioną zmianę należy oceniać pozytywnie.

${ }^{19}$ Na marginesie można tylko wskazać, że zarząd sukcesyjny może zostać również ustanowiony po śmierci przedsiębiorcy przez jego małżonka lub spadkobiercę i wtedy następuje z chwilą dokonania wpisu w CEIDG zarządcy sukcesyjnego (art. 12 ust. $1 \mathrm{w}$ zw. $\mathrm{z}$ art. 7 ust. $1 \mathrm{pkt} 2$ ).

${ }^{20}$ R. Kapkowski, M. Kaufmann, Charakter prawny zarzadcy sukcesyjnego na tle pokrewnych instytucji zarzadu masa spadkowa, ,Rejent” 2019, nr 7, s. 54-88. 
Powyższe rozwiązanie jest interesujące, jednak z uwagi na fakt, że znajduje zastosowanie wyłącznie po śmierci przedsiębiorcy, a nie po jego zaginięciu, samodzielnie wykorzystane przez przedsiębiorcę nie wpływa w żaden sposób na stan przedsiębiorstwa, jeżeli ten tylko zaginął.

\section{Wnioski}

Od czasu przyjęcia w 2012 roku nowej definicji legalnej zaginięcia skala takich przypadków w Polsce rośnie. Trudno oszacować liczbę zaginięć przedsiębiorców, gdyż takiej statystyki się nie prowadzi, jednak nawet jeśli są one nieliczne, to rodzaj problemów pojawiających się wówczas i liczba podmiotów dotkniętych skutkami takiego zdarzenia wymagają poszukiwania sensownych rozwiązań prawnych.

Ponieważ przedsiębiorcy stanowią szczególną grupę społeczną i zaginięcie któregokolwiek z przedsiębiorców może powodować niepowetowaną szkodę dla jego sfery majątkowej i przez to sfery majątkowej jego ewentualnych pracowników, kontrahentów, klientów, czy wreszcie spadkobierców, budzi wątpliwości, dlaczego ustawodawca nie przewidział praktycznie żadnych mechanizmów, które znajdowałyby zastosowanie automatycznie w sytuacji zgłoszenia czy nawet ustalenia zaginięcia takiej osoby.

Zaginięcie nie powoduje przecież uznania nieistnienia przedsiębiorcy, a przez to nie wywołuje praktycznie żadnych skutków prawnych w sferze majątkowej przedsiębiorstwa.

Wobec powyższego, mimo że zaginiony przedsiębiorca faktycznie nie prowadzi przedsiębiorstwa, podczas jego niezawinionej nawet nieobecności aktualizują się jego zobowiązania, w szczególności zobowiązania majątkowe w sferze publicznej i prywatnej, które mogą doprowadzić do roztrwonienia jego majątku.

Negatywnie należało ocenić dotychczasowe rozwiązania prawne stosowane na wypadek zaginięcia przedsiębiorcy, z których samodzielnie żadne w pełni nie rozwiązywało problemu zabezpieczenia przedsiębiorstwa na wypadek jego zaginięcia. Co więcej, większość rozwiązań jest nierealnych w wypadku zaginięcia przedsiębiorcy, gdyż zawsze jest to zdarzenie nagłe, niemożliwe do przewidzenia.

Instytucja prowadzenia cudzych spraw bez zlecenia pozwala na prowadzenie doraźnych spraw przedsiębiorcy pod jego nieobecność, co 
może pozwolić na podjęcie niezbędnych działań w celu zachowania jego formuły do czasu, aż zostaną podjęte czynności prawne pozwalające na wyłonienie przedstawiciela przedsiębiorcy działającego na podstawie i w granicach udzielonego mu umocowania. Powyższe rozwiązanie jednak nie pozwala na faktyczne swobodne prowadzenie spraw przedsiębiorcy i zapewnienie ciągłości prowadzonej działalności gospodarczej.

Wszak dokonując czynności prawnej, podejmujący się prowadzić sprawy przedsiębiorcy bez zlecenia działa najczęściej w imieniu zainteresowanego jako jego pełnomocnik rzekomy (falsus procurator), a zatem czynności dokonane przezeń na zewnątrz są bezskuteczne i wymagają potwierdzenia przez uprawnioną osobę, a jednostronne czynności prawne dokonane przez taką osobę są nieważne (art. 103-105 k.c.).

Powyższe może wywoływać wątpliwości lub w ogóle nie pozwolić na ustalenie bezskuteczności czy nieważności czynności dokonywanych z pracownikami, kontrahentami lub klientami przedsiębiorcy.

Możliwość ustanowienia kuratora absentis, który jest instytucją niezależną od woli przedsiębiorcy, który nie ma wiedzy na temat przedsiębiorstwa, który nie może samodzielnie dokonywać żadnych czynności przekraczających zwykły zarząd, a którego ustanowienie wymaga czasu (a ten jest wyjątkowo cenny w szybko zmieniającej się rzeczywistości), w praktyce nie realizuje funkcji ochronnej przywołanych wyżej podmiotów.

Udzielenie przez przedsiębiorcę zaś samego pełnomocnictwa osobie trzeciej pozwalającego na kierowanie przedsiębiorstwem należało ocenić jako rozwiązanie mało elastyczne, wymagające bowiem od przedsiębiorcy podjęcia próby przewidzenia, jakich czynności będzie wymagało prowadzenie działalności gospodarczej, oceny, które czynności stanowią zwykły zarząd przedsiębiorstwem, a które ten zwykły zarząd przekraczają, a w ekstremalnych przypadkach również czynności wymagających pełnomocnictwa szczególnego. Mogło również w konkretnych sytuacjach prowadzić do wątpliwości, czy dana czynność dokonana przez pełnomocnika wywołuje skutki prawne.

W kontekście powyższego należy pozytywnie dla zabezpieczenia sytuacji zaginionego przedsiębiorcy ocenić systemowe zmiany wprowadzone przez ustawodawcę do polskiego porządku prawnego $\mathrm{w}$ ramach tzw. konstytucji biznesu. 
Trudno ocenić, czy taki efekt jest zamierzonym działaniem ustawodawcy, ale ustawą z dnia 6 marca 2018 roku przyznał on możliwość ustanowienia prokury przez jednoosobowego przedsiębiorcę, a następnie ustawą z dnia 5 lipca 2018 roku uregulował zasady zarządu sukcesyjnego przedsiębiorstwem jednoosobowego przedsiębiorcy, dając mu możliwość wskazania prokurenta jako zarządcy sukcesyjnego, który ma prowadzić przedsiębiorstwo i zapewnić ciągłość jego funkcjonowania na wypadek jego śmierci.

Wymienione rozwiązanie systemowe pozwala na zapewnienie w sytuacji zaginięcia przedsiębiorcy możliwości kontynuowania działalności gospodarczej przedsiębiorcy przez prokurenta, który został wybrany przez przedsiębiorcę, a zatem można domniemywać, że ma wiedzę i umiejętności niezbędne do zajmowania się jego przedsiębiorstwem, i który ma uprawnienie do prowadzenia spraw sądowych i pozasądowych związanych z prowadzeniem przedsiębiorstwa już od daty nastąpienia zdarzenia uniemożliwiającego ustalenie miejsca pobytu przedsiębiorcy.

W tej sytuacji zminimalizowane jest niebezpieczeństwo, że sprawy przedsiębiorcy istotne dla prowadzenia działalności gospodarczej nie będą prowadzone.

Taki prokurent ma bowiem prawo, ale i obowiązek dbania o interesy przedsiębiorcy, którego reprezentuje. Dysponuje on szeroką gamą możliwości, będąc umocowanym przezzaginionego do prowadzenia spraw sądowych i pozasądowych związanych z prowadzeniem działalności gospodarczej.

Może on zatem niezwłocznie po powzięciu wiadomości o zaginięciu przedsiębiorcy przystąpić do zabezpieczenia przedsiębiorstwa i prowadzenia jego spraw.

Jako prokurent wyznaczona osoba nie może zbyć przedsiębiorstwa, oddać przedsiębiorstwa do czasowego korzystania czy zbyć lub obciążać nieruchomości, przy czym o ile to ostatnie może ograniczyć możliwości prokurenta $\mathrm{w}$ zakresie pozyskiwania kapitału na prowadzenie działalności gospodarczej, o tyle należy pamiętać, że sytuacja zaginięcia przedsiębiorcy jest sytuacją szczególną i, jak się wydaje, zadaniem prokurenta przede wszystkim w takiej sytuacji byłoby zachowanie przedsiębiorstwa i prowadzenie go w zastępstwie przedsiębiorcy, w oczekiwaniu na jego odnalezienie. 
Ponieważ prokura wygasa z chwilą śmierci, dzięki nowemu rozwiązaniu zarządu sukcesyjnego, z tym momentem ten sam prokurent z mocy ustawy może stać się zarządcą sukcesyjnym przedsiębiorstwa osoby fizycznej, która poniosła śmierć lub została uznana za zmarłego.

Wraz z datą śmierci czy uznania przedsiębiorcy za zmarłego prokurent, już jako ustanowiony przez przedsiębiorcę zarządca sukcesyjny, może przystąpić do zarządzania przedsiębiorstwem oraz kontynuowania działalności gospodarczej wykonywanej z wykorzystaniem przedsiębiorstwa przedsiębiorcy we własnym imieniu, choć na rachunek właścicieli przedsiębiorstwa w spadku.

Nie ma również niebezpieczeństwa, że czynności dokonane przez prokurenta po śmierci przedsiębiorcy zostaną podważone jako bezskuteczne lub jako nieważne. Jako zarządca sukcesyjny prokurent dysponuje uprawnieniami i obowiązkami jak sam przedsiębiorca, a zatem może nie tylko dokonywać czynności związanych z prowadzeniem działalności gospodarczej, ale również je potwierdzać.

Takie kompleksowe rozwiązanie może zapewnić znaczną ochronę interesów majątkowych przedsiębiorcy oraz jego spadkobierców na wypadek, gdyby ten zaginął lub, w ekstremalnych sytuacjach, gdyby poniósł w okresie zaginięcia śmierć.

Winno się jednak pamiętać, że takie rozwiązanie, choć należy je oceniać pozytywnie, zależne jest od woli przedsiębiorcy i tego, aby przed swoim zaginięciem ustanowił on prokurenta, jak również wskazał go jako zarządcę sukcesyjnego.

Należy postulować, aby niezależnie od przywołanych wyżej rozwiązań ustawodawca zaplanował mechanizmy niezależne od woli przedsiębiorców, które znajdowałyby zastosowanie w sytuacji zaginięcia przedsiębiorcy z mocy prawa i pozwalały na niezwłoczne zabezpieczenie jego majątku na czas jego poszukiwań. Powyższe pozwoliłoby w wyższym stopniu odpowiedzieć na rosnące w tym zakresie potrzeby społeczeństwa. 


\section{Bibliografia}

Bieluk J., Ustawa o zarządzie sukcesyjnym przedsiębiorstwem osoby fizycznej. Komentarz, wyd. 1, Warszawa 2019.

Kapkowski R., Kaufmann M., Charakter prawny zarzadcy sukcesyjnego na tle pokrewnych instytucji zarządu masą spadkowa, ,Rejent” 2019, nr 7, s. 54-88.

Kodeks Cywilny. Komentarz, red. J. Ciszewski, P. Nazaruk, WKP 2019.

Kodeks rodzinny i opiekuńczy. Komentarz, red. J. Wierciński, WKP 2014.

Kowalski J., Kiedy zaginą człowiek. Podstawowe informacje prawne, Warszawa 2012, http:// www.itaka.org.pl/wp-content/uploads/2015/01/Kiedy-zagin $\% C 4 \% 85 \%$ C5\%82-czowiek-informacje-prawne.pdf (dostęp: 26.01.2020).

Podstawowa informacja o działalności sąów powszechnych - I pótrocze 2017 roku na tle poprzednich okresów statystycznych, https://isws.ms.gov.pl/pl/baza-statystyczna/publikacje/ (dostęp: styczeń 2020).

Raport o stanie sektora małych i średnich przedsiębiorstw w Polsce, red. R. Zakrzewski, A. Skowrońska, Warszawa 2019.

Wentkowska A., Poszukiwania osób zaginionych. System i metody działania w procedurach stużb, Warszawa 2016, https://www.rpo.gov.pl/sites/default/files/Poszukiwania $\% 20$ osób\%20zaginionych\%20-\%20Aleksandra\%20Wentkowska\%20-monografia\%20 2016.pdf (dostęp: 26.01.2020).

Zaporowski P. et al., Polskie prawo firmowe. Zagadnienia wybrane, Wrocław 2016, http:// bibliotekacyfrowa.pl/Content/76594/Zaporowski_P_Polskie_prawo_firmowe_zagadnienia_wybrane.pdf (dostęp: 26.01.2020).

\section{Akty prawne}

Konstytucja Rzeczypospolitej Polskiej z dnia 2 kwietnia 1997 roku, Dz.U. 1997 Nr 78, poz. 483, art. 22 .

Ustawa z dnia 6 marca 2018 roku o Centralnej Ewidencji i Informacji o Działalności Gospodarczej i Punkcie Informacji dla Przedsiębiorcy, Dz.U. 2019 poz. 1291, tekst jednolity z dnia 12 lipca 2019.

Ustawa z dnia 6 marca 2018 roku Prawo przedsiębiorców, Dz.U. 2019 poz. 1292, tekst jednolity z dnia 12 lipca 2019.

Ustawa z dnia 5 lipca 2018 roku o zarządzie sukcesyjnym przedsiębiorstwem osoby fizycznej i innych ułatwieniach związanych z sukcesją przedsiębiorstw, Dz.U. 2018 poz. 1629.

Zarządzenie nr 48 Komendanta Głównego Policji z dnia 28 czerwca 2018 roku w sprawie prowadzenia przez Policję poszukiwania osoby zaginionej oraz postępowania w przypadku ujawnienia osoby o nieustalonej tożsamości lub znalezienia nieznanych zwłok oraz szczątków ludzkich, Dziennik Urzędowy Komendy Głównej Policji 2018, poz. 77 . 


\section{Źródła internetowe}

Strona internetowa policji: http://statystyka.policja.pl/st/wybrane-statystyki/zaginieni/ 50885,Zaginieni.html (dostęp: styczeń 2020).

\section{Disappearance of an entrepreneur and business operations - an outline of the problem}

\section{Summary}

This article provides an outline of the analysis of problems caused by the disappearance of an entrepreneur in the context of his business.

The purpose of the publication is to draw attention to the previously overlooked aspect of the disappearance of a natural person conducting business activities.

The disappearance of an entrepreneur raises a number of separate problems not only in the personal sphere, but above all in the property sphere of the entrepreneur, his employees, contractors, or clients.

The author of this article has analyzed the legal consequences of an entrepreneur's disappearance in the context of his business. Then he identified the legal institutions implemented by the legislator, which can be used to avoid, or at least mitigate the negative effects of the said disappearance, and made their practical analysis in relation to the case of disappearance of an entrepreneur actively conducting business activities. This analysis was the basis for proposing a comprehensive solution through the joint use of several legal institutions operating in the legal regime to obtain the most effective protection of business participants in the event of the disappearance of an entrepreneur. Finally, he assessed the functioning legal institutions and proposed in which direction the legislator's further actions should be taken to regulate the increasingly important problem of the disappearance of a participant of business trading.

The aforementioned analysis led the author to the conclusion that the disappearance does not cause the entrepreneur's non-existence to be recognized, and thus has virtually no legal effect on the property of the enterprise.

In view of the above, despite the fact that the missing entrepreneur does not actually run the enterprise, during his unavoidable absence, his liabilities become chargeable, in particular property liabilities, in the public and private sphere, which may lead to the squandering of his assets, and at the same time to the violation of the interests of third parties related to the process of doing business.

While the application of several legal institutions may limit the harmful effects of an entrepreneur's disappearance on his property sphere and third parties, including those involved in business transactions, the legal solutions possible to apply in the event of an entrepreneur having gone missing should be evaluated negatively. In particular, none of them alone fully solves the problem of securing an enterprise in the event of disappear- 
ance, and most solutions are simply unreal in the event of an entrepreneur having gone missing.

In practical terms, highlighting the problem of an entrepreneur's disappearance from the point of view of its legal effects and the possibility of removing its negative consequences will increase its rank in the assessment of search institutions and may contribute to the development of new solutions.

It should be postulated that regardless of the analyzed solutions, the legislator plans and introduces mechanisms independent of the will of a missing entrepreneur, which would be applicable in the event of the disappearance of an entrepreneur by law, and allow immediate protection of his assets during his search. The above would make it possible to respond to the growing needs of society in this respect.

Keywords: entrepreneurs, disappearance of an entrepreneur, enterprise of a missing entrepreneur, business activity after disappearance, the assets of the missing entrepreneur. 